\title{
BLOOD VOLUME STUDIES IN SHOCK RESULTING FROM MYO- CARDIAL INFARCTION. I. STUDIES WITH EVANS BLUE DYE (T-1824) ${ }^{1}$
}

\author{
By CLARENCE M. AGRESS, MARVIN ROSENBURG, ABRAHAM SCHNEIDER- \\ MAN, AND E. J. BROTMAN \\ (From the Medical Service, Wadsworth Hospital, Veterans Administration Center and \\ the Department of Medicine, University of California, Los Angeles, Calif.)
}

(Submitted for publication, April 24, 1950; accepted, June 20, 1950)

The ominous form of circulatory failure which may accompany severe myocardial infarction carries a distressing mortality of some $79 \%$ (1). The clinician confronted with the treatment of this condition finds the pathogenesis obscure (2), the relation of primary heart failure to peripheral circulatory failure confused (3), and his therapy often futile. Recently the trend has been to use blood and plasma as is done in better understood forms of shock (4-6), in spite of the prevailing conclusion that this form of failure of the circulation is not, like hemorrhagic and traumatic shock, accompanied by a fall in blood volume $(2,3,7,8 a)$.

This work was therefore undertaken to determine what changes occur in the blood volume after acute myocardial infarction, since a survey of the literature showed that previous studies were few and in our opinion not conclusive. In another paper (9) the authors have presented the evidence for believing that Evans blue dye ( $\mathrm{T}-1824)$ is a valid method for studying the circulating blood volume in shock, provided the sources of error are recognized and certain criteria are observed (see Methods). This dye was selected because it has an extensive clinical and experimental background for use in shock and because it has proved superior to all other methods.

After critical appraisal of the literature it was our impression that no real conclusions as to blood volume changes are justified. The earliest clinical study was made by Fishberg and associates (7) in 1934. These authors concluded that "the volume of circulating blood tends to be diminished," although criticism of their data has been made by Gross (10) that "only one case had

\footnotetext{
1 Sponsored by the Veterans Administration and published with the approval of the Chief Medical Director. The statements and conclusions of the authors are the result of their own study and do not necessarily reflect the opinion or policy of the Veterans Administration.
}

an unequivocally subnormal blood volume." Although the studies were carefully made, the Congo Red method in use at that time introduced a large error because of its diffusibility. Due to this defect it is no longer in general use. These workers were the first to point out that in the day or two following infarction the blood volume increased as heart failure complicated the shock picture; yet only one patient in shock out of their 29 cases was studied in the first 24 hours. Since this form of cardiogenic shock cannot always be distinguished clinically from congestive heart failure complicated by peripheral circulatory collapse, it is most important that the blood volume be measured in the first few hours after infarction has occurred.

The next study was done by Stead and Ebert (3) in 1942. Six patients presenting shock following infarction were studied with T-1824. In five cases the plasma volume was slightly smaller than the expected volume based on height and in one case it was normal. As the authors point out, several of these patients were in congestive heart failure at the time the plasma volume was determined. Circulating whole blood volumes were not calculated. They also suggest that in the cases without preceding heart failure, the slight reduction in plasma volumes found and the hemoconcentration present may have been due to loss of fluid into the lungs. A study by Cameron (11) on five patients does not distinguish shocked from unshocked cases and hence affords no evidence of the state of the blood volume in cardiogenic shock.

On the experimental side the only blood volume studies were made by Gross, Mendlowitz and Schauer $(10,12,13)$. Here again the Congo Red method was used. The authors themselves point out that at the time the blood volume studies were 
made, there was no significant reduction of blood pressure over that of control studies, since in their animals the major fall in blood pressure after coronary ligation occurred after 24 hours. While the correlation is not perfect, in general the degree of reduction of blood pressure parallels the severity of shock. Therefore, the blood volume studies made here are studies following coronary ligation in dogs and are not comparable to the form of severe circulatory collapse seen in man.
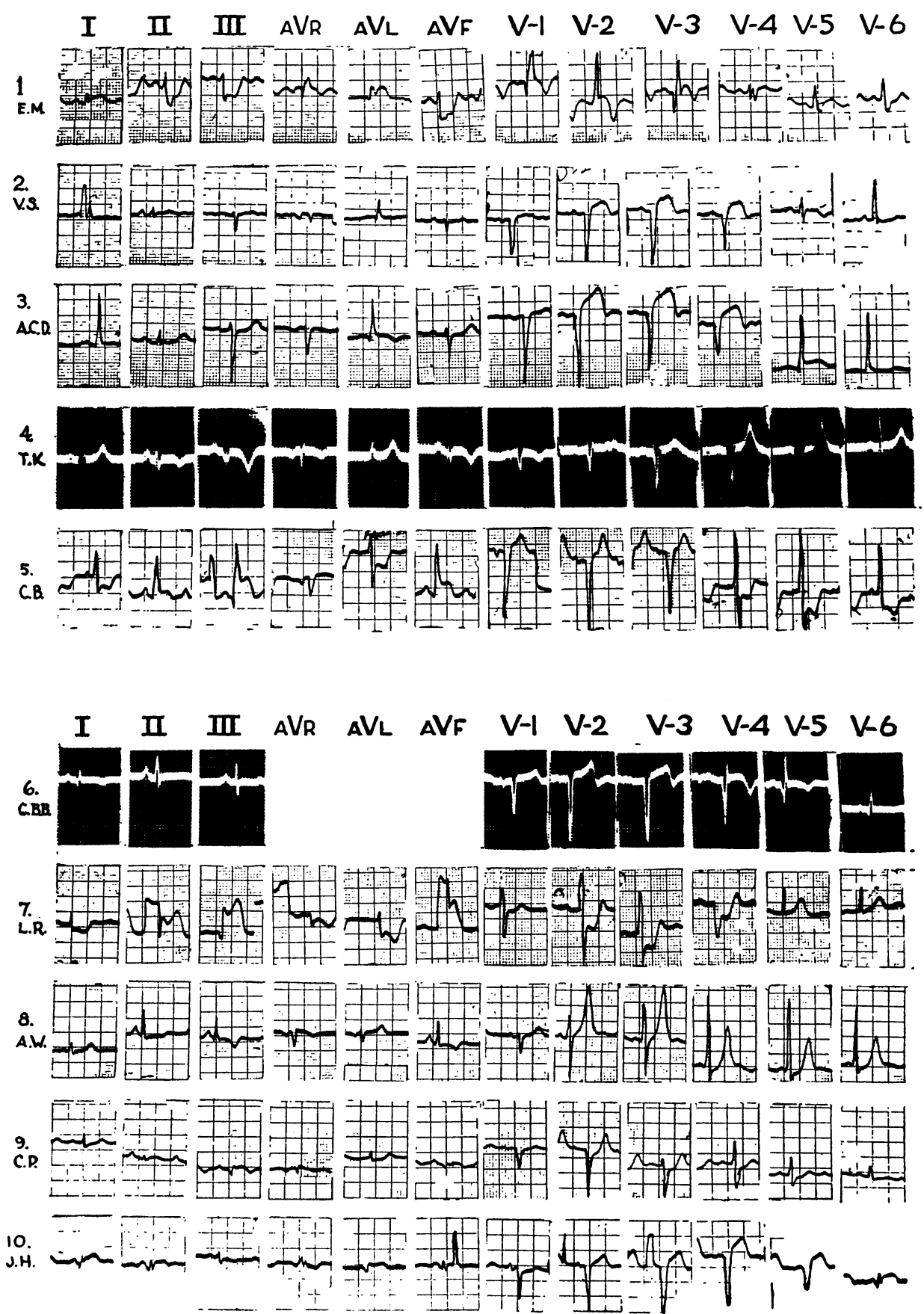

Fig. 1. 


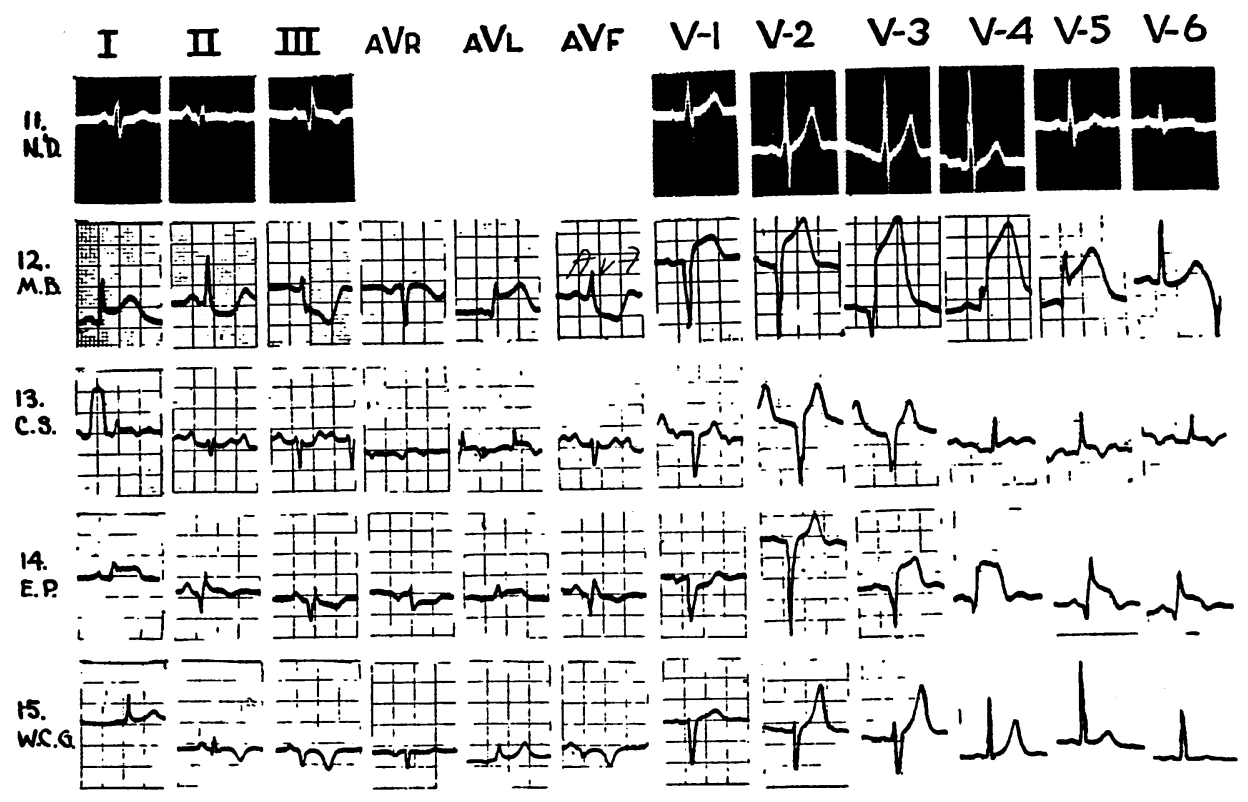

$\begin{array}{llllllllllll}I & \text { III III } & A V R & A V L & A V F & V-1 & V-2 & V-3 & V-4 & V-5 & V-6\end{array}$
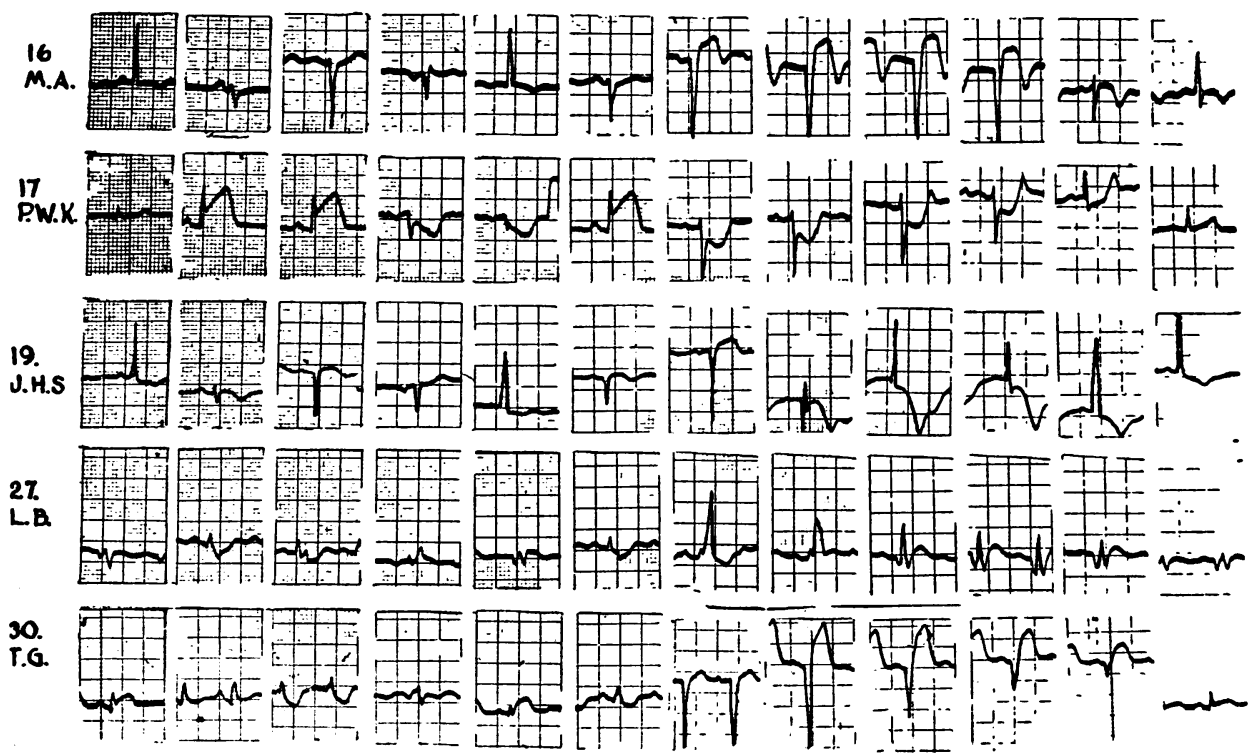

Fig. 1. (Cont.)

\section{METHODS}

Cases of acute myocardial infarction only were used in this study. The authors served as a team to insure that all determinations and procedures would be carried out by the same workers. When cases were admitted to the hospital, this team was notified immediately. The cases selected not only had a clear-cut clinical picture of acute myocardial infarction but were required to show unmistakable ECG changes (Figure 1) or autopsy confirmation of infarction (Table I). Those cases so selected were divided into three groups: cases without shock, with moderate shock, and with severe shock. Moderate shock was distinguished from severe shock by the general status of the patient but in order to facilitate this distinction, certain convenient criteria were used. Patients were considered severely shocked if the pulse rate was greater than 120 per minute, the systolic blood pressure less 
than $80 \mathrm{~mm}$. $\mathrm{Hg}$, the sensorium definitely dulled, sweating marked, the pulse pressure less than $20 \mathrm{~mm}$. $\mathrm{Hg}$, the skin showing marked pallor and/or cyanosis, and definite oliguria present. It is important to remember that the blood pressure alone may be misleading in patients previously hypertensive who may have suffered a marked drop in blood pressure without, however, a fall to hypotensive levels. Cases complicated by arrhythmias which may have contributed to the circulatory failure were discarded. Cases complicated by severe anemia, polycythemia or other diseases known to influence the blood volume were also discarded. The following procedures were carried out on each patient: History, physical examination, routine blood count and urinalysis, serum proteins, electrocardiogram, portable chest $x$-ray, venous pressure (14), and circulation times with sodium dehydrocholate (decholin). Systolic blood pressures were determined by palpation in those cases where the level was too low for auscultation. In some cases direct mean intra-arterial pressures were determined by the use of a manometer connected to the femoral artery. Blood volume determinations were performed with Evans blue dye ( $T$-1824) according to the method of Gregersen (15). Special precautions were taken to avoid hemolysis, loss of dye, infiltration of the tissues, etc. (9). In all shock cases 15 minute arterial sampling was obtained. (Robinow and Hamilton have shown that in normal patients mixing is complete in 30-90 seconds [16]. Gregersen states that in severe shock after hemorrhage or skeletal trauma the mixing time "is increased but not indefinitely prolonged" and that an average value was 15 minutes [17].) Serial blood volume determinations were performed wherever possible. The final determinations were made at least one month after recovery to insure a sufficiently long interval for adequate restoration of the normal circulatory dynamics. Allowance was made for any change in weight. ${ }^{2}$ Many of the cases had parallel blood volume determinations using red cells incubated with radioactive phosphorus. More complete data utilizing this latter technique will be the subject of another communication.

In practice, it was found exceedingly difficult in borderline cases to distinguish shock from congestive heart failure. Many of the physiologic alterations of heart failure are well known to occur in shock. Elevation of the peripheral venous pressure and even of the central venous pressure to levels of $16-20 \mathrm{~cm}$. of water has been shown to occur in cases of shock following trauma, hemorrhage, or burns $(8 b, 18-20)$. It cannot, therefore, be taken as an absolute indication of the presence of congestive heart failure. Prolongation of the circulation time also may occur in shock or heart failure (21). There-

2 Plasma was calculated from the formula P.V. $=\frac{\text { conc. of dye } \times \text { vol. of dye }}{\text { conc. of dye in sample }}$

Whole blood volume was then determined by the formula

$$
\text { W.B.V. }=\frac{\text { plasma volume }}{1-\text { hematocrit }}
$$

fore, for clarity of study it was assumed that heart failure was present if the venous pressure were higher than $20 \mathrm{~cm}$. water ; the liver congested, either as shown by a $5 \mathrm{~cm}$. or more rise of venous pressure on compression of the liver or by autopsy finding of severe chronic passive congestion; the presence of marked serous effusions; peripheral edema; or an increase in the transverse diameter of the heart not caused by previous heart disease.

In order to test the validity of the Evans blue dye technique of blood volume determinations in our hands, determinations were carried out on a group of normal patients. It was found that multiple checks of their blood volumes ranged from 75 to $95 \mathrm{cc}$. per $\mathrm{kg}$. This corresponds with those values reported by other workers (22, 23). In polycythemia values averaging $104 \mathrm{cc}$. per $\mathbf{k g}$. were found, whereas patients in congestive heart failure averaged $116 \mathrm{cc}$. per $\mathrm{kg}$. Two patients having acute blood loss were followed with serial blood volume determinations. Following their acute episodes, the blood volumes were found to average $49 \mathrm{cc}$. per $\mathrm{kg}$. while after recovery they rose to an average of $80 \mathrm{cc}$. per $\mathrm{kg}$.

At the present time it is not felt that sufficient data have been amassed to justify a report based on radioactive phosphorus ( $\mathrm{P}-32$ ) blood volume determinations. At the beginning of this project, technical details, such as the long incubation period of the phosphorus with the subject's blood, prohibited its use in critically ill patients. Simultaneous determinations of P-32 and T-1824 done when these same patients were convalescent revealed a mean ratio of 0.80 ( $\mathrm{P}-32 / \mathrm{T}-1824)$. This compares favorably with an average deviation of 0.87 reported by Reeve and Veall $(24,25)$.

\section{RESULTS}

The results obtained on the cases studied have been summarized in Tables II, III, and IV. Table V summarizes the clinical data on shocked patients. A statistical summary of average serum and whole blood volumes is to be found in Table VI, together with the percentile changes from the normal. This normal value is determined at the completion of convalescence, or in case of the patient's death, from the expected blood volume based on weight (22). These cases are divided according to the amount of time elapsing from the onset of the attack to the blood volume determination. Table VI summarizes the data on patients remaining in each group after the elimination of those who exhibited congestive heart failure as determined by the use of our arbitrary criteria. It will be seen that in those patients without shock the average whole blood volume was $83.6 \mathrm{cc}$. per $\mathrm{kg}$. This was only a +2.0 per cent deviation from the whole blood volume found after recovery, and does not represent a significant change. In the 


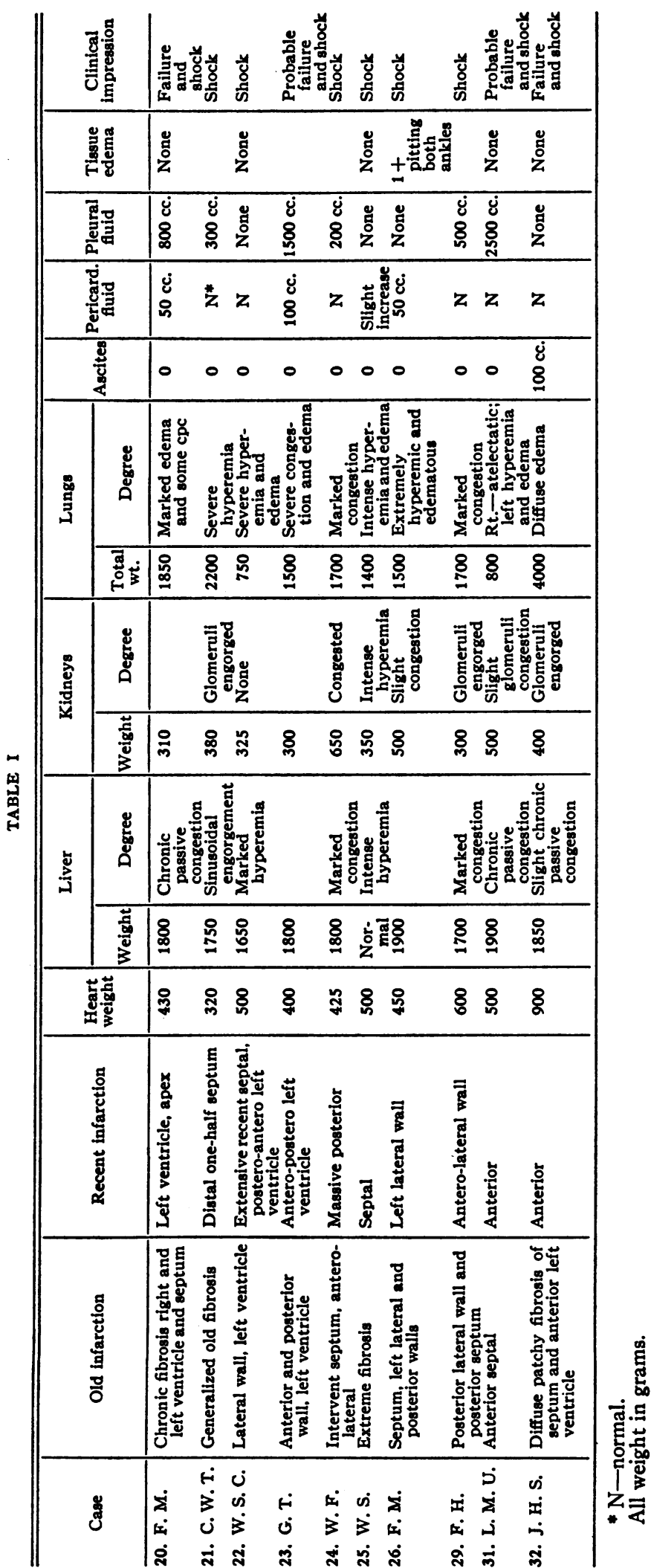


TABLE II

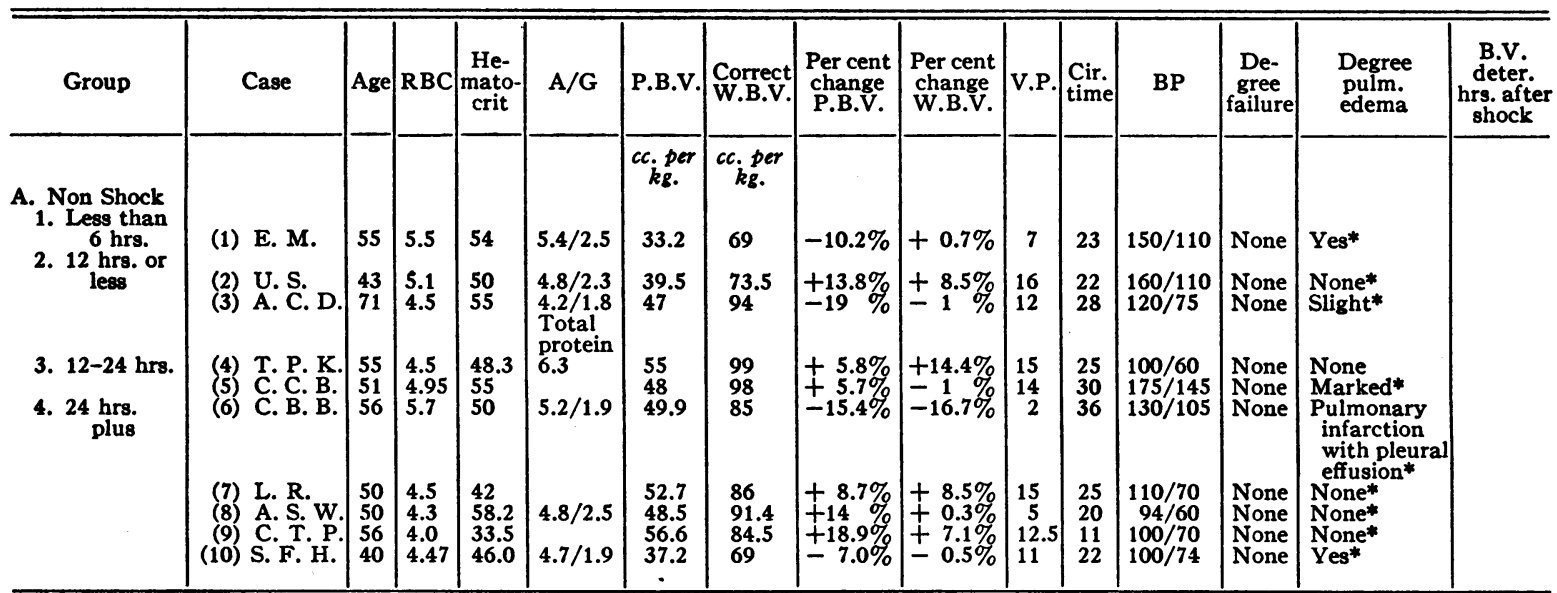

RBC - Red blood count in millions

A/G -Albumin, globulin ratio

P.B.V. -Plasma blood volume in cc. per $\mathrm{kg}$. of

cc. per kg. body weight

Correct W.B.V. - Whole blood volume, in cc. per $\mathrm{kg}$. of

cc. per kg. body weight, corrected for trapped plasma

Per cent change-Per cent change in plasma blood volume

P.B.V.

Per cent change-Per cent change in whole blood volume

W.B.V.

moderately shocked patients the average whole blood volume was $72.4 \mathrm{cc}$. per $\mathrm{kg}$., with a -15.6 per cent deviation. The severely shocked patients had an average whole blood volume of $73.5 \mathrm{cc}$. per kg., with a -16.1 per cent deviation. All groups showed a relatively greater loss of plasma than whole blood volume. If the moderate and severely shocked patients are grouped together
V.P. -Venous pressure in centimeters of water

Circ. Time - Circulation time in seconds using sodium dehydrocholate

BP -Blood pressure in millimeters of mercury

B.V. Deter.-Hrs. after shock-Interval in hours between onset of shock and blood volume determination

* $\quad-X$-ray evidence of the presence or absence of N.E.P. -No end points

excluding those cases with a clear-cut clinical picture of congestive heart failure, the average reduction of the whole blood volume is -16.0 per cent. If the patients showing congestive heart failure are included, then the average reduction is only - 7.0 per cent. These latter patients not only showed clinical evidence of heart failure but were found to have expanded blood volumes as well.

TABLE III

\begin{tabular}{|c|c|c|c|c|c|c|c|c|c|c|c|c|c|c|c|}
\hline Group & Case & Age & $R B C$ & $\begin{array}{c}\text { He- } \\
\text { mato- } \\
\text { crit }\end{array}$ & A/G & P.B.V. & $\begin{array}{l}\text { Correct } \\
\text { W.B.V. }\end{array}$ & $\begin{array}{l}\text { Per cent } \\
\text { change } \\
\text { P.B.V. }\end{array}$ & $\begin{array}{l}\text { Per cent } \\
\text { change } \\
\text { W.B.V. }\end{array}$ & V.P. & $\begin{array}{l}\text { Cir. } \\
\text { time }\end{array}$ & BP & $\begin{array}{l}\text { Degree } \\
\text { failure }\end{array}$ & $\begin{array}{l}\text { Degree } \\
\text { pulm. } \\
\text { edema }\end{array}$ & $\begin{array}{l}\text { B.V. } \\
\text { deter. } \\
\text { hrs. } \\
\text { after } \\
\text { shock }\end{array}$ \\
\hline $\begin{array}{l}\text { B. Moderate } \\
\text { Shock } \\
\text { 1. 0-6 hrs. } \\
\text { 2. 6-12 hrs. } \\
\text { 3. } 12-24 \text { hrs. } \\
\text { 4. } 24 \text { hrs. } \\
\text { plus }\end{array}$ & $\begin{array}{l}\text { (11) N. N. } \\
\text { (12) M. A. B. } \\
\text { (13) C. S. } \\
\text { (14) } \text { E. P. } \\
\text { (15) W. C. G. } \\
\text { (16) M. A. } \\
\text { (17) P. E. K. } \\
\text { (18) J. H. S. } \\
\text { (19) R. M. } \\
\text { (20) F. M. } \\
\text { (20) F. M. }\end{array}$ & $\cdot \begin{array}{l}38 \\
51 \\
52 \\
55 \\
69 \\
54 \\
51 \\
56 \\
64 \\
35\end{array}$ & $\begin{array}{l}5.0 \\
4.95 \\
5.2 \\
5.7 \\
4.93 \\
5.2 \\
4.4 \\
4.1 \\
5.5 \\
5.1 \\
4.7\end{array}$ & $\begin{array}{l}44.5 \\
47 \\
52 \\
50.3 \\
42 \\
48 \\
43 \\
38 \\
46 \\
46.5 \\
43\end{array}$ & $\begin{array}{l}4.9 / 2.6 \\
3.6 / 2.5 \\
5.1 / 1.4 \\
4.3 / 2.0 \\
4.7 / 2.0 \\
4.8 / 2.7\end{array}$ & \begin{tabular}{|l}
$c c$. per \\
kg. \\
\\
39 \\
29.6 \\
41.2 \\
32 \\
57.7 \\
40.2 \\
44.9 \\
71.2 \\
35 \\
50.2 \\
53
\end{tabular} & $\begin{array}{c}c c . \text { per } \\
\text { kg. } \\
\\
67 \\
52 \\
79.4 \\
60.5 \\
92 \\
72.5 \\
77.9 \\
109 \\
60.6 \\
94 \\
93.2\end{array}$ & $\begin{array}{l}-18 \% \\
-39.5 \% \\
-25.2 \% \\
-28 \% \\
+11 \% \\
-20.2 \% \\
+7.1 \% \\
+10.4 \% \\
\\
+11.6 \% \\
+17.8 \%\end{array}$ & $\begin{array}{l}-9.5 \% \\
-35.4 \% \\
-23.7 \% \\
-20.5 \% \\
-11 \% \\
-17.6 \% \\
+8.5 \% \\
+1.9 \% \\
+10.6 \% \\
+9.6 \%\end{array}$ & $\begin{array}{r}12 \\
15 \\
11 \\
8 \\
16 \\
4 \\
4 \\
24 \\
7 \\
7 \\
19 \\
21\end{array}$ & $\begin{array}{c}30 \\
23 \\
37 \\
23 \\
20 \\
16 \\
15 \\
\text { No } \\
\text { deter. } \\
30 \\
23\end{array}$ & $\begin{array}{c}140 / 95 \\
160 / 100 \\
110 / 84 \\
120 / 92 \\
95 / 70 \\
120 / 70 \\
92 / 60 \\
\text { Unobtain- } \\
\text { able } \\
180 / 120 \\
120 / 80 \\
95 / 75 \\
104 / 74\end{array}$ & $\begin{array}{l}\text { None } \\
\text { None } \\
\text { No } \\
\text { No } \\
\text { None } \\
\text { None } \\
\text { None } \\
\text { Yes } \\
\text { None } \\
\text { Moder- } \\
\text { ate } \\
\text { Severe }\end{array}$ & $\begin{array}{l}\text { None } \\
\text { Moderate* } \\
\text { Severe } \\
\text { Severe* } \\
\text { Mild } \\
\text { None } \\
\text { None } \\
\text { Severe } \\
\text { Moderate } \\
\text { Moderate* } \\
\text { Moderate }\end{array}$ & $\begin{array}{c}4 \\
10 ? \\
12-14 \\
14.5 ? \\
10\end{array}$ \\
\hline
\end{tabular}

* See Table II (also for abbreviations). 
TABLE IV

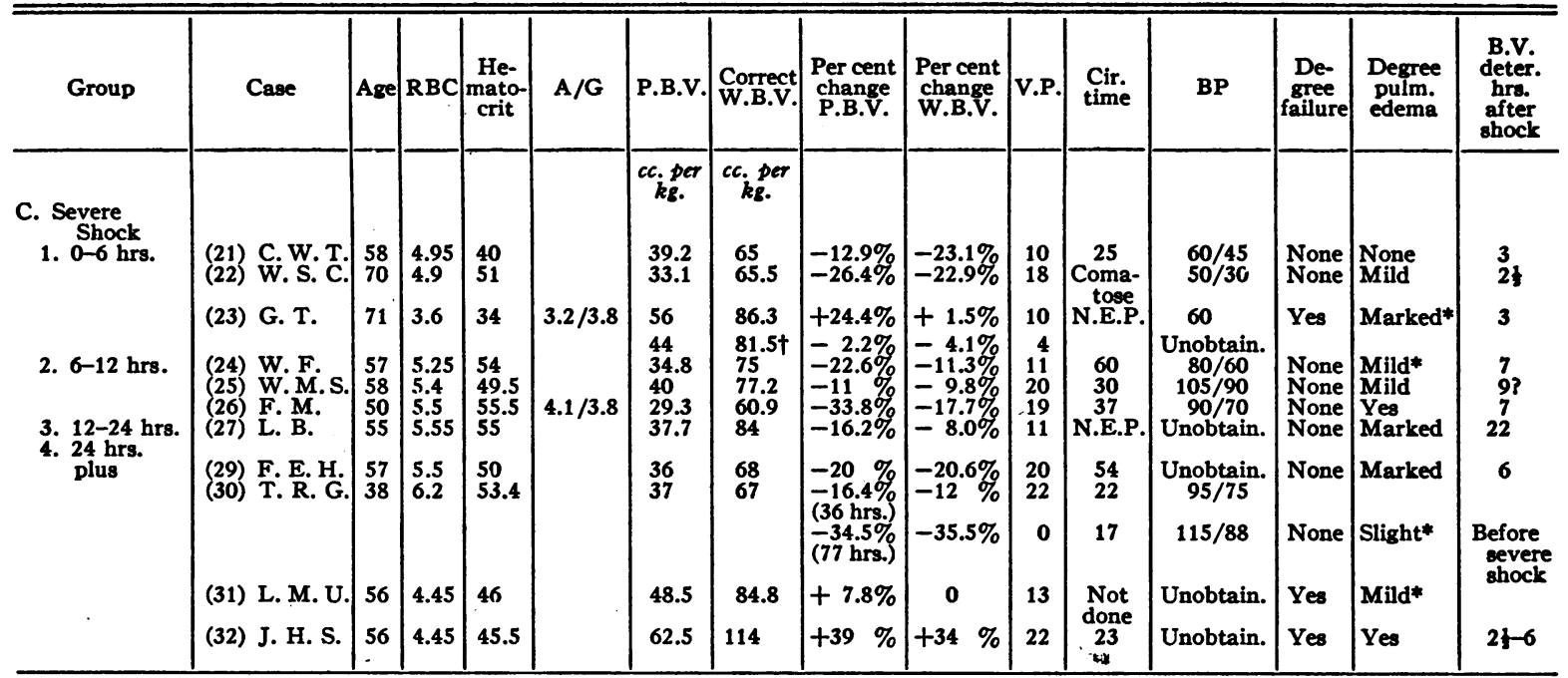

† See case history.

* See Table II (also for abbreviations).

TABLE V

Findings in shocked patients

\begin{tabular}{|c|c|c|c|c|c|c|c|c|c|c|}
\hline \multirow{2}{*}{ Case } & \multirow{2}{*}{ Sensorium } & \multirow{2}{*}{$\begin{array}{l}\text { Skin } \\
\text { temp. }\end{array}$} & \multirow{2}{*}{ Skin color } & \multirow{2}{*}{$\begin{array}{c}\text { Sweat- } \\
\text { ing }\end{array}$} & \multirow{2}{*}{ BP } & \multicolumn{2}{|c|}{ Pulse } & \multirow{2}{*}{$\begin{array}{l}\text { Pulm. } \\
\text { rales }\end{array}$} & \multirow{2}{*}{$\begin{array}{l}\text { Pulm. edema } \\
\text { chest } x \text {-ray }\end{array}$} & \multirow{2}{*}{$\begin{array}{l}\text { Classi- } \\
\text { fication } \\
\text { of shock }\end{array}$} \\
\hline & & & & & & Rate & Character & & & \\
\hline $\begin{array}{l}\text { 11. N. D. } \\
\text { 12. M. B. } \\
\text { 13. C. F.S. } \\
\text { 14. E. H.P. } \\
\text { 15. W. G. } \\
\text { 16. M. A. } \\
\text { 17. P. E. K. } \\
\text { 18. J. H. S. }\end{array}$ & $\begin{array}{l}\text { Clear } \\
\text { Narcotized } \\
\text { Depressed } \\
\text { Clear } \\
\text { Narcotized } \\
\text { Clear } \\
\text { Dull } \\
\text { Alert }\end{array}$ & $\begin{array}{l}\text { Warm } \\
\text { Warm } \\
\text { Cool } \\
\text { Cool } \\
\text { Warm } \\
\text { Cool } \\
\text { Cool } \\
\text { N }\end{array}$ & $\begin{array}{l}\text { Cyanotic } \\
\text { N } \\
\text { Pale } \\
\text { Pale } \\
\text { N } \\
\text { Cyanotic } \\
\text { Cyanotic } \\
\text { Pale and }\end{array}$ & $\begin{array}{l}(0-4+) \\
0 \\
1+ \\
2+ \\
2+ \\
0 \\
1+ \\
1+ \\
0\end{array}$ & $\begin{array}{c}140 / 95 \\
160 / 100 \\
110 / 184 \\
120 / 92 \\
95 / 70 \\
120 / 70 \\
92 / 60 \\
92 \text { by }\end{array}$ & $\begin{array}{r}66 \\
60 \\
128 \\
104 \\
60 \\
85 \\
110 \\
96\end{array}$ & $\begin{array}{l}\text { Weak } \\
\text { Weak } \\
\text { Weak } \\
\text { Weak } \\
\text { Full } \\
\text { Weak } \\
\text { Weak } \\
\text { Weak }\end{array}$ & $\begin{array}{l}(0-4+) \\
0 \\
0 \\
3+ \\
1+ \\
0 \\
0 \\
0 \\
0\end{array}$ & $\begin{array}{l}\text { Clear } \\
\text { Clear } \\
\text { Marked } \\
\text { Marked } \\
\text { Mild } \\
\text { None } \\
\text { None } \\
\text { Severe }\end{array}$ & $\begin{array}{l}\text { Mild } \\
\text { Mild } \\
\text { Mild } \\
\text { Mild } \\
\text { Mild } \\
\text { Mild } \\
\text { Mild } \\
\text { Mild }\end{array}$ \\
\hline 19. R. M. & Depressed & $\mathrm{N}$ & Pale and & $2+$ & $\begin{array}{l}\text { palp. } \\
180 / 120\end{array}$ & 90 & Weak & $1+$ & Moderate & Mild \\
\hline 20. F. M. & Dull & Warm & Slight & 0 & $95 /$ & 120 & Weak & $3+$ & & Mild \\
\hline 21. C. W. T. & $\begin{array}{c}\text { Markedly } \\
\text { depressed }\end{array}$ & Warm & $\begin{array}{l}\text { cyanosis } \\
\text { Cyanotic }\end{array}$ & $2+$ & $60 / 45$ & 120 & Weak & 0 & None & Severe \\
\hline 22. W. S. C. & Depressed & Cool & Cyanotic & $3+$ & $85 / 60$ & $\begin{array}{c}38 \\
\text { comp. ht. }\end{array}$ & Full & $2+$ & None & Severe \\
\hline 23. G. T. & Normal & Cold & Pale & $3+$ & 60 by & $\begin{array}{c}\text { block } \\
106\end{array}$ & Thready & $2+$ & Severe & Severe \\
\hline $\begin{array}{l}\text { 24. W. F. } \\
25 . \text { W.S. } \\
\text { 26. F. M. }\end{array}$ & $\begin{array}{l}\text { Depressed } \\
\text { Sedated } \\
\text { Dull }\end{array}$ & $\begin{array}{l}\text { Warm } \\
\text { Cool } \\
\text { Cold }\end{array}$ & $\begin{array}{l}\text { Cyanotic } \\
\text { Pale } \\
\text { Pale and }\end{array}$ & $\begin{array}{l}1+ \\
1+ \\
2+\end{array}$ & $\begin{array}{r}\text { palp. } \\
80 / 60 \\
105 / 90 \\
92 / 70\end{array}$ & $\begin{array}{c}80 \text { irreg. } \\
104 \\
95\end{array}$ & $\begin{array}{l}\text { Weak } \\
\text { Weak } \\
\text { Feeble }\end{array}$ & $\begin{array}{l}2+ \\
1+ \\
1+\end{array}$ & $\begin{array}{l}\text { Mild } \\
\text { Moderate } \\
\text { None }\end{array}$ & $\begin{array}{l}\text { Severe } \\
\text { Severe } \\
\text { Severe }\end{array}$ \\
\hline 27. L. B. & Stuporous & Cool & $\begin{array}{l}\text { Pale and } \\
\text { cyanotic }\end{array}$ & $2+$ & 0 & 96 & Feeble & $3+$ & None & Severe \\
\hline 29. F. H. & Alert & Cold & Cyanotic & $4+$ & 0 & 120 & Impercep- & $2+$ & None & Severe \\
\hline 30. T. R. G. & Alert & Cool & Pale and & $3+$ & $95 / 75$ & 120 & Thready & $2+$ & Mild & Severe \\
\hline 31. L. M. U. & $\begin{array}{l}\text { Semi- } \\
\text { comatose }\end{array}$ & Cold & $\begin{array}{l}\text { Pale and } \\
\text { cyanotic }\end{array}$ & $2+$ & $0 / 0$ & & $\begin{array}{l}\text { Impercep- } \\
\text { tible, ht. }\end{array}$ & $2+$ & & Severe \\
\hline 32. J. H. S. & Clear & Warm & $\begin{array}{l}\text { Slightly } \\
\text { pale and } \\
\text { cyanotic }\end{array}$ & 0 & $0 / 0$ & $\begin{array}{c}96 \\
\text { apical }\end{array}$ & $\begin{array}{l}\text { Impercep- } \\
\text { tible }\end{array}$ & $1+$ & $!$ & Severe \\
\hline
\end{tabular}


TABLE VI

\begin{tabular}{|c|c|c|c|c|c|c|}
\hline & $\begin{array}{l}\text { Time after } \\
\text { infarct }\end{array}$ & $\begin{array}{c}\text { Aver- } \\
\text { age } \\
\text { pl. } \\
\text { voi- } \\
\text { ume }\end{array}$ & $\begin{array}{l}\text { Aver- } \\
\text { age } \\
\text { W.B. } \\
\text { vol- } \\
\text { ume }\end{array}$ & $\begin{array}{c}\text { Per } \\
\text { cent } \\
\text { change } \\
\text { pl. V. }\end{array}$ & $\begin{array}{c}\text { Per } \\
\text { cent } \\
\text { change } \\
\text { W.B.V. }\end{array}$ & $\begin{array}{l}\text { No. of } \\
\text { deter- } \\
\text { mina- } \\
\text { tions }\end{array}$ \\
\hline & & $\begin{array}{l}c c . \\
\text { per } \\
\text { kg. }\end{array}$ & $\begin{array}{l}c c . \\
\text { per } \\
k g .\end{array}$ & & & \\
\hline $\begin{array}{l}\text { Non } \\
\text { shock } \\
\text { cases }\end{array}$ & $\begin{array}{l}0-6 \text { hours } \\
6-12 \text { hours } \\
12-24 \text { hours } \\
24 \text { hours plus } \\
\text { total average }\end{array}$ & $\begin{array}{l}33.2 \\
43.3 \\
50.6 \\
49.0 \\
44.0\end{array}$ & $\begin{array}{l}69.0 \\
83.8 \\
98.5 \\
83.2\end{array}$ & $\begin{array}{r}-10.2 \\
-\quad 2.6 \\
+5.8 \\
+3.8 \\
+\quad 1.5\end{array}$ & $\begin{aligned}+ & 0.7 \\
+ & 3.8 \\
+ & 6.7 \\
+ & 0.3 \\
+ & 2.0\end{aligned}$ & $\begin{array}{r}1 \\
2 \\
2 \\
5 \\
10\end{array}$ \\
\hline $\begin{array}{l}\text { Moderate } \\
\text { shock } \\
\text { cases }\end{array}$ & $\begin{array}{l}0-6 \text { hours } \\
6-12 \text { hours } \\
12-24 \text { hours } \\
24 \text { hours plus } \\
\text { total average }\end{array}$ & $\begin{array}{l}34.3 \\
36.6 \\
49.0 \\
44.9 \\
41.2\end{array}$ & $\begin{array}{l}59.5 \\
70.0 \\
82.3 \\
77.9 \\
72.4\end{array}$ & $\begin{array}{r}-28.8 \\
-26.6 \\
-4.6 \\
+7.4 \\
-16.1\end{array}$ & $\begin{array}{r}-22.4 \\
-22.1 \\
-9.3 \\
+8.5 \\
-15.6\end{array}$ & $\begin{array}{l}2 \\
2 \\
2 \\
1 \\
7\end{array}$ \\
\hline $\begin{array}{l}\text { Severe } \\
\text { shock } \\
\text { cases }\end{array}$ & $\begin{array}{l}0-6 \text { hours } \\
6-12 \text { hours } \\
12-24 \text { hours } \\
24 \text { hours plus } \\
\text { total average }\end{array}$ & $\begin{array}{l}36.1 \\
34.7 \\
37.7 \\
40.5 \\
37.3\end{array}$ & $\begin{array}{l}65.3 \\
71.0 \\
84.0 \\
73.3 \\
73.4\end{array}$ & $\begin{array}{l}-19.7 \\
-22.6 \\
-16.2 \\
-15.8 \\
-18.6 \\
\end{array}$ & $\begin{array}{r}-23.0 \\
-12.9 \\
-8.0 \\
-17.0 \\
-16.1\end{array}$ & $\begin{array}{r}2 \\
4 \\
1 \\
4 \\
11\end{array}$ \\
\hline
\end{tabular}

\section{DISCUSSION}

This is a report on the blood volume changes in 32 patients with acute myocardial infarction. In this study emphasis was placed on the following points :

1. Each patient presented absolute evidence of myocardial infarction, either by ECG or autopsy changes.

2. Patients with complicating diseases which might also affect the blood volume were not included.

3. A meticulous technique utilizing Evans blue dye (T-1824) was employed. The errors inherent in this technique are recognized and discussed in a paper previously cited (9). Hemolysis and lipemia which are easily recognized are the only important errors of technique which might falsely lower the blood volume. All of the other errors involve dye loss which gives a falsely expanded volume (26). Since the blood volume figures obtained in this study were low, it is apparent that no errors of technique were involved. Hence, the reduced blood volumes in shocked patients must represent a real trend.

4. Wherever possible the normal figure for each patient's blood volume was taken after the circulation had become stabilized. In this way, whatever error introduced by the use of an expected normal blood volume based on body measurements, was eliminated.
5. An attempt was made to place carefully the time of infarction with relation to the time the blood volume was determined, since congestive heart failure may be superimposed on the initial shock syndrome after only a few hours have elapsed.

It is interesting to note that when the per cent deviation from the normal blood volume is plotted against the time elapsing from the onset of infarction, the three groups seem to give different curves. The non-shock group shows a flat curve with no significant deviation from the expected normal. The cases shocked so severely that death resulted show a persistently low blood volume with a progressive decline. The moderately shocked cases (recovery) show an initially low blood volume which increases with the passage of time to normal or to an expanded blood volume. These trends are being further investigated because they seem to be significant. The hematocrit values which were obtained in the three groups are of great interest because of the lack of any great difference between the mild-shock and severe-shock cases. A similar observation has been made by Gregersen in the study of traumatic and hemorrhagic shock. He points out that the only forms of shock which are regularly accompanied by hemoconcentration are those caused by burns and peritonitis where large plasma losses occur (17). Further study is needed before any conclusions can be drawn from hematocrit data of this kind.

We would like to point out certain weaknesses of this study:

1. While shock and heart failure are customarily considered separate and distinct entities, it was found very difficult in many seriously ill patients to separate "central" from "peripheral circulatory failure." It is well recognized that in contradistinction to the ordinary forms of shock which are associated with a decreased blood volume, congestive heart failure is accompanied by an increased blood volume. Since congestive heart failure often complicates shock following myocardial infarction, unless its presence is recognized, the effect of shock on reducing the blood volume may not be apparent. The classical use of peripheral venous pressures to distinguish shock from heart failure, in which the venous pressure is low in 
shock and elevated in congestive failure, may fail in studying patients of this type. In our hands venous pressures were not infrequently found to be elevated in severely shocked patients showing extreme vasoconstriction but without evidence of heart failure. Other authors have found peripheral venous pressure to be elevated in shock following trauma, hemorrhage or burns $(8 b, 18-20)$. The resolution of this problem must await a clearer understanding of the physiological disturbance occurring in both shock and heart failure.

2. All present methods of blood volume determination are open to criticism. At the present time Evans blue dye gives the smallest percentile error, as determined by many reliable investigators $(2,14,27-29)$. Further simultaneous studies using both $\mathrm{T}-1824$ and radioactive phosphorus $(\mathrm{P}-32)$ are in progress.

\section{SUMMARY AND CONCLUSIONS}

1. Blood volume studies in 32 cases of myocardial infarction are reported in this paper. These cases have been classified into three groups : non-shock (10 cases), moderate shock (10 cases), severe shock (12 cases).

2. The average blood volume of the non-shock cases was $84 \mathrm{cc}$. per $\mathrm{kg}$.; of the moderately shocked cases $72 \mathrm{cc}$. per $\mathrm{kg}$.; and of the severely shocked cases $73 \mathrm{cc}$. per $\mathrm{kg}$.

3. Blood volume determinations were done on all surviving patients after convalescence when the circulatory system had returned to normal. There were no significant changes in the blood volumes of those patients not exhibiting shock. Those patients with shock showed a 16.0 per cent reduction.

4. In general, patients with a clear-cut picture of peripheral circulatory failure had a reduced blood volume, in contrast to the expanded blood volumes of patients with congestive heart failure. In several instances there was a reduction of the blood volume during the shock and later expansion during the failure phase.

5. Moderate elevations of the peripheral venous pressure have been observed in several patients showing shock, but without clinical signs of heart failure. These patients had no history of previous myocardial infarction or congestive heart failure.

\section{ACKNOWLEDGMENT}

The authors wish to acknowledge their indebtedness to Drs. Samuel H. Bassett, Thomas F. Barrett, Roger O. Egeberg for many helpful suggestions in the preparation of this work; also to Dr. Raymond L. Libby and Dr. Max Fields for all of the technical advice in the radioactive phosphorus studies.

\section{CASE SUMMARIES}

11. N. D. This 39 year old white male was admitted to the hospital complaining of severe chest pain of ten hours duration. The pain could only be relieved by opiates. Physical examination revealed a short obese white male. He was slightly cyanotic and although he had a normal blood pressure and pulse was considered to be in mild shock. Serial electrocardiograms revealed a posterior myocardial infarction. The shock disappeared with bed rest, oxygen, and relief of pain.

12. M. A. B. This 49 year old white male entered the hospital because of substernal pain and weakness of four hours duration. He gave a history of angina pectoris of six months duration. The patient was obese, moderately cyanotic, and slightly dyspneic. His blood pressure was $160 / 100$ and pulse 110 . He had previously had a systolic pressure of 230 . Electrocardiogram showed a recent antero-septal myocardial infarction. He continued to have severe chest pain off and on for several days and developed bilateral rales with cough. He was placed on penicillin and anticoagulant therapy. He developed a pericardial friction rub and his blood pressure fell to 112/ 80. Subsequently, he developed evidence of mild congestive failure and was digitalized. Remaining hospital course was uneventful and the patient recovered.

13. C. S. This 52 year old male entered the hospital approximately 12 hours after onset of severe chest pain. He gave no history of previous cardiac disease. On admission his blood pressure was $110 / 85$ and pulse 128 . He was somewhat dyspneic, pale, perspiring, and his skin was cool. There was moderately severe pulmonary edema. Venous pressure was $15 \mathrm{~cm}$. of water and the circulation time was 23 seconds. Electrocardiogram showed an anterior myocardial infarction. The treatment was routine and the patient recovered.

14. E. P. This 55 year old white male entered the hospital ten hours after onset of a burning chest pain that radiated to both shoulders, forearms, and epigastrium. He had had a previous posterior infarction in 1942. On admission he was pale, dyspneic, and perspiring. His body was cool. There were bilateral basal rales. Blood pressure was 120/92 but dropped rapidly to $98 / 50$. Venous pressure was $11 \mathrm{~cm}$. of water. Circulation time was 27 seconds by decholin. A $250 \mathrm{cc}$. blood transfusion was given at the time of the initial drop in blood pressure and on two occasions on the next day with good responses. Remaining treatment was routine. The patient recovered.

15. W. C. G. This 69 year old white male entered the hospital because of moderately severe substernal pain 
which radiated into the left arm. On admission the blood pressure was $95 / 70$ and pulse 60 . Electrocardiogram showed a typical posterior infarction. In the afternoon of the first hospital day the patient received $500 \mathrm{cc}$. of blood because of the appearance of progressively more severe shock. On the third hospital day there was evidence of mild left failure. This was treated with mercurial diuretics. An attempt to digitalize the patient was abandoned because of the appearance of complete heart block which later returned to normal. After a long convalescence the patient recovered.

16. M. A. This 53 year old white male entered the hospital 11 days after onset of symptoms. He had had severe chest pain for 14 hours until relieved by opiates. On admission he was cyanotic and his blood pressure was $120 / 70$, a fall from $170 / 120$. There was no evidence of failure. On auscultation it was thought that a gallop was heard. Electrocardiogram showed an anterior myocardial infarction. Treatment was routine. The patient recovered.

17. P. E. K. This 51 year old white male entered the hospital 36 hours after onset of pain which had remained for four hours. There were no previous cardiac symptoms. On admission his blood pressure was $92 / 60$. Electrocardiogram showed a posterior-lateral infarction. There was no evidence of cardiac failure. Treatment was routine and recovery was satisfactory.

18. J. H. S. This 56 year old white male entered the hospital complaining of chest pain of six days duration. Blood volume studies were begun on his third hospital day at which time his blood pressure was $0 / 0$ by auscultation and 92 by palpation. The pulse was 96 . He was cyanotic, pale, dyspneic, and slightly orthopneic. The liver was palpable $2 \mathrm{~cm}$. below the costal margin and tender. A diastolic gallop was heard over the mitral area. The patient was given intravenous cedilanid. Forty-five minutes later his venous pressure had fallen from 21 to $16 \mathrm{~cm}$. of water with dramatic improvement. The remainder of the treatment was routine. The patient was discharged to domiciliary care.

19. R. M. This 64 year old white male entered the hospital because of chest pain. He gave a history of previous infarction, failure and hypertension. The blood volume studies were begun three or four days after onset of the infarction. At that time his blood pressure had dropped from a hypertensive level to $120 / 80$. He was pale, sweating, and cyanotic. Electrocardiogram showed posterior myocardial infarction, although some pulmonary edema was present. The patient recovered without difficulty on routine management.

20. F. M. This 35 year old white male entered the hospital two hours after the onset of chest pain. He gave a history of previous episodes of chest pain but electrocardiograms were apparently normal. On admission he was in mild shock, having a blood pressure of 95/75 and being slightly cyanotic. Heart tones were poor. A diastolic gallop was heard. Electrocardiogram showed an extensive anterior myocardial infarction. Patient did poorly and 48 hours later appeared to be in a state of shock. Blood volume studies were done at this time. Patient was digitalized. On his fifth hospital day the patient complained of sharp pain in the upper gastric region which did not radiate but was aggravated by lying on his left side. The liver was noted to be enlarged and further measures to combat congestive failure were undertaken; however, the liver continued to enlarge and was tender on palpation. A right sided pleural effusion was noted and $400 \mathrm{cc}$. of a dark amber fluid were removed. $1,000 \mathrm{cc}$. of air were removed from the stomach by Levine tube later that afternoon. Next morning the patient died suddenly.

At autopsy the heart weighed 430 grams and showed chronic fibrosis throughout the right and left ventricles and the septum. There was a recent infarction involving the left ventricle. The liver weighed 1,800 grams and showed central congestion. The lungs weighed a total of $1,880 \mathrm{grams}$ and were the site of marked edema. There was a total of $800 \mathrm{cc}$. of fluid in the pleural spaces.

21. C. W. T. This 58 year old white male entered the hospital two and one-half hours after onset of severe chest pain. On admission he appeared to be in severe shock. His skin showed a cyanotic mottling. The pulse was unobtainable. The blood pressure was $65 / 40$. Electrocardiogram showed an extensive anterior infarction. Intravenous plasma was started immediately. Neither the plasma nor stimulants were helpful. The patient died three hours after admission.

At autopsy an extensive recent infarction was found. The lungs weighed a total of 2,200 grams and showed marked edema and hyperemia. The liver weighed 1,750 grams and showed only minimal hyperemia.

22. W. S. C. This 70 year old diabetic, white male had onset of chest pain 72 hours before admission. His blood pressure was $120 / 80$ and there was no evidence of shock or failure. Blood sugar was $336 \mathrm{mg}$. per cent and the $\mathrm{CO}_{2}$ combining power was 48 volumes per cent. The urine showed a 4.5 per cent sugar and four plus acetone. Electrocardiogram showed a recent anterior and an old posterior myocardial infarction. The patient received anticoagulants, opiates, insulin and 1,000 cc. of 5 per cent glucose in water by clysis. The next day his blood pressure had dropped to $80 / 50$, his pulse was irregular and his body was cold and clammy. Blood sugar was $732 \mathrm{mg}$. per cent and $\mathrm{CO}_{2} 30$ volumes per cent. The patient received coramine, neosynephrine, whole blood (total of $600 \mathrm{cc}$.) intravenously and acetyl strophanthidin, and cedilanid intravenously without improvement. He died 17 hours after admission.

At autopsy no free fluid was found in the pleural spaces. The lungs weighed a total of 750 grams. There was minimal edema and hyperemia. The liver weighed 1,650 grams and showed acute central lobular degeneration and hyperemia. The heart showed a recent extensive myocardial infarction.

23. G. T. This 71 year old white male had had severe chest pain for seven hours when first seen. He was a mild diabetic and had one leg amputated because of arteriosclerotic gangrene. He had been on digitalis. 
At the time of the first blood volume study the blood pressure was 60 by palpation. The pulse was almost imperceptible and the rate was 106 . The patient was pale, cool, sweating, and slightly cyanotic. The patient received $500 \mathrm{cc}$. of plasma, $450 \mathrm{cc}$. of blood intravenously and $400 \mathrm{cc}$. of blood intra-arterially. $\mathrm{He}$ also received Khellin intramuscularly, strophanthin, and digitoxin but died within a few hours.

Autopsy was performed and showed 750 cc. of fluid in each pleural cavity. The heart showed extensive myocardial infarction. The lungs weighed a total of 1,500 grams and showed severe hyperemia, alveolar edema and early pneumonia. The liver weighed 1,800 grams and showed severe central lobular necrosis and hyperemia.

24. W. F. This 57 year old white male entered the hospital after seven hours of chest pain. He had been vomiting and having loose bowel movements. $\mathrm{He}$ had had a previous less severe episode six months earlier. On admission the patient was depressed by opiates. He was sweating and was slightly cyanotic. The heart tones were faint. The blood pressure was $80 / 60$. The pulse was irregular with a rate of 80 . The liver was $6 \mathrm{~cm}$. below the costal margin. The electrocardiogram revealed a recent posterior infarction and a complete $\mathrm{A}-\mathrm{V}$ block. The patient died shortly after receiving $500 \mathrm{cc}$. of plasma.

At autopsy $100 \mathrm{cc}$. of fluid were found in each pleural cavity. The lungs weighed a total of 1,700 grams and showed moderate hyperemia and edema. The liver weighed 1,800 grams and acute central hyperemia was present microscopically. The heart was the site of a severe recent myocardial infarction.

25. W. M. S. This 58 year old white male entered the hospital because of severe left chest pain of nine hours duration. He stated that in the past his blood pressure had been as high as 210 . On admission the patient was complaining of severe chest pain. Blood pressure was 90 by palpation, pulse 140 , and respiration was 24. He was mildly cyanotic, perspiring, pale and cool. Lungs were clear except for a few basal rales. Electrocardiogram showed evidence of recent anterior infarction and possible old posterior infarction. He was given $5 \mathrm{mg}$. of neosynephrine with no rise in blood pressure. The three units of acetyl strophanthidin were given with no improvement. A $250 \mathrm{cc}$. intravenous blood transfusion was started but was stopped because the venous pressure rose from 20 to 26 centimeters while the shock deepened. The needle was then placed in the femoral artery and over a period of one hour and twenty minutes another $250 \mathrm{cc}$. of blood was given. The blood pressure rose from 60 to 78, there was no change in venous pressure and the pulse slowed from 130 to 112 . It seemed that he was improving but he had a sudden convulsion with death resulting.

Autopsy revealed no free fluid in the pleural cavity. The heart showed extensive recent and old myocardial infarction. The lungs weighed a total of 1,400 grams and showed moderate edema and hyperemia. The liver showed minimal hyperemia.
26. F. M. This 50 year old white male entered complaining of substernal pain of seven hours duration, which had not been relieved by previous morphine or demerol injections. He gave a history of having three prior coronary occlusions. Physical examination revealed an acutely ill dyspneic, cyanotic, white male with a blood pressure of $92 / 70$, which rapidly became imperceptible. There were basal rales in the lungs. Patient was placed under oxygen and sent to a medical ward and expired a few minutes after arrival despite intravenous adrenalin and coramine.

27. L. B. This 55 year old white male entered the hospital approximately 22 hours after onset of acute substernal pain. $\mathrm{He}$ had been hospitalized eight months previously because of an anterolateral myocardial infarction. He had had angina only on two occasions and had no other return of cardiac symptoms until onset of present episode. On physical examination an acutely ill, cyanotic, orthopneic white male was seen. The blood pressure was not obtainable and the pulse was 96 , weak and thready. Heart sounds were of poor quality and the patient was comatose. Both lungs were filled with coarse rales. Electrocardiogram revealed extensive changes consisting of a right bundle branch block and evidence of old and recent anterior myocardial infarctions. He was given 250 cc. of plasma slowly without improvement. Patient died soon after a blood transfusion was begun.

29. F. E. H. This 56 year old white male was brought to the hospital because of a 24 hour history of substernal pain radiating to his left arm, profuse perspiration, and nausea. He gave a history of hypertension and angina. On admission the patient appeared critically ill, cold, clammy and cyanotic. Blood pressure was $60 / 40$ and pulse was 110. Heart sounds were distant, there were moist fine rales at the right base, there was no peripheral edema. Electrocardiogram revealed a posterior myocardial infarction. An hour after admission a bloodless phlebotomy was done. An hour later $500 \mathrm{cc}$. of blood were withdrawn and this was followed by extreme diaphoresis. Blood pressure fell to $0 / 0$, and his pulse became imperceptible. Fifty cc. of serum albumin were given intravenously. However, his condition remained unchanged until death.

On autopsy $500 \mathrm{cc}$. of fluid were found in each pleural cavity and the heart revealed recent and old myocardial infarction. The lungs weighed a total of 1,700 grams and showed moderate hyperemia and edema with terminal pneumonia. Liver weighed 1,700 grams and was the site of acute central hyperemia and moderate degenerative changes.

30. T. R. G. This 38 year old white male entered the hospital because of severe chest pain which radiated into his left arm, shoulder, back and jaw. Onset of pain was 36 hours before admission. Patient gave a strong family history of heart disease. On physical examination patient showed some cyanosis, blood pressure was 104/80, pulse 140 . Heart tones were decreased. There was no evidence of failure. Electrocardiogram 
showed a recent myocardial infarction. After admission to the hospital his blood pressure continued to fall slowly; and sweating became profuse. The systolic pressure fell to 90 . He was given $5 \mathrm{mg}$. of neosynephrin without effect. A $500 \mathrm{cc}$. intravenous tranfusion failed to reverse rapid downward trend. $\mathrm{He}$ was then given $700 \mathrm{cc}$. of blood into the femoral artery. There was gradual improvement from that point. The pulse slowed from 130 to 108 and the blood pressure rose from 83 to 100 by palpation. The sweating decreased and the skin became warmer. An hour later his blood pressure had risen to 114/70. Patient's remaining hospital course was satisfactory and he recovered after a long convalescence.

31. L. M. U. This 56 year old white male was admitted to the hospital because of two episodes of severe substernal pain. He gave a history of a heart attack one and one-half years previous. On admission a moderately orthopneic, pale, cyanotic white male in acute distress was seen. There were bilateral basal rales. The liver was three centimeters below the right costal margin. The skin was cool, moist, and the nail beds were cyanotic. Neck veins were distended. Electrocardiogram showed anterior myocardial changes. Approximately one month after admission patient had recurrence of chest pain and again two weeks later. On the last occasion the pain was associated with dyspnea and a shock-like picture. The electrocardiogram showed a definite posterior myocardial infarction. The blood pressure dropped to $60 / 0$ and he continued in this shock-like condition until his death later that day.

At postmortem bilateral pleural effusions were found totaling 2,800 cc. Heart showed evidence of old and recent myocardial infarction. The lungs weighed a total of 1,600 grams. There was evidence of hemosiderosis without evidence of hyperemia. The liver weighed 1,900 grams. There was evidence of acute central degeneration with hyperemia.

32. J. H. S. This 56 year old white male was admitted to the hospital with a history of shortness of breath of ten days duration. He had been discharged 16 days previously from the hospital where he had received treatment for acute myocardial infarction (case 18). Patient experienced only a slight degree of chest pain. Physical examination revealed no evidence of shock or failure. On admission the patient was placed on digitalis, mercuhydrin, and bed rest. On the third day the patient became excited and experienced a sharp pain across his chest. He became cyanotic and oxygen and papaverine were started with some relief, but the patient died two days later.

At autopsy no free pleural fluid was found. The heart revealed old myocardial infarcts and focal areas of recent infarction. Lungs weighed a total of 4,000 grams. Minimal alveolar edema but marked hyperemia were present microscopically. Liver weighed 1,850 grams and showed acute hyperemia and occasional central lobular degeneration.

\section{BIBLIOGRAPHY}

1. Billings, F. T., Jr., Kalstone, B. M., Spencer, J. L., Ball, C. O. T., and Meneely, G. R., Prognosis of acute myocardial infarction. Am. J. Med., 1949, 7, 356.

2. Boyer, N. H., Cardiogenic shock. New England J. Med., 1944, 230, 226.

3. Stead, E. A., and Ebert, R. V., Shock syndrome produced by failure of the heart. Arch. Int. Med., 1942, 69, 369.

4. Schwartz, W. B., The treatment of shock accompanying myocardial infarction. Am. Heart J., 1947, 33, 169.

5. Corday, E., Bergman, H. C., Schwartz, L. L., Spritzler, R. J., and Prinzmetal, M., Studies on the coronary circulation. IV. The effect of shock on the heart and its treatment. Am. Heart J., 1949, 37,560 .

6. Sampson, J. J., and Singer, I. M., Plasma and blood infusion following myocardial infarction. Am. Heart J., 1949, 38, 54.

7. Fishberg, A. M., Hitzig, W. M., and King, F. H., Circulatory dynamics in myocardial infarction. Arch. Int. Med., 1934, 54, 997.

8. Davis, H. A., Shock and Allied Forms of Failure of the Circulation. Grune and Stratton, New York, 1949. (a) p. 342 ; (b) p. 86.

9. Agress, C. M., Schneiderman, A., and Rosenburg, M. J., Evaluation of the use of Evans blue dye (T-1824) in shock. To be published.

10. Gross, L., Mendlowitz, M., and Schauer, G., Hemodynamic studies in experimental coronary occlusion; open chest experiments. Am. Heart J., 1937, $13,647$.

11. Cameron, W. M., Hilton, J. H. B., Townsend, S. R., and Mills, E. S., Importance of blood changes in coronary occlusion. Canad. M. A. J., 1947, 56, 263.

12. Mendlowitz, M., Schauer, G., and Gross, L., Hemodynamic studies in experimental coronary occlusion; closed chest experiments. Am. Heart J., 1937, 13, 664.

13. Mendlowitz, M., Schauer, G., and Gross, L., Hemodynamic studies in experimental coronary occlusion; denervated heart experiments. Am. Heart J., 1937, 14, 21.

14. Winsor, T., and Burch, G. E., Use of phlebomanometer; normal venous pressure values and a study of certain clinical aspects of venous hypertension in man. Am. Heart J., 1946, 31, 387.

15. Gregersen, M. I., A practical method for the determination of blood volume with the dye T-1824; survey of present basis of dye-method and its clinical applications. J. Lab. \& Clin. Med., 1944, 29, 1266.

16. Robinow, M., and Hamilton, W. F., Blood volume and extracellular fluid volume of infants and children; studies with improved dye micromethod 
for determination of blood volume. Am. J. Dis. Child., 1940, 60, 827.

17. Gregersen, M. I., Symposium on physiological contributions to war problems; physiological contributions to the problem of shock. Federation Proc., 1946, 50, 354 .

18. Cournand, A., Riley, R. L., Bradley, S. E., Breed, E. S., Noble, R. P., Lauson, H. D., Gregersen, M. I., and Richards D. W., Studies of the circulation in clinical shock. Surgery, 1943, 13, 964.

19. Kohlstaedt, K. G., and Page, I. H., Terminal hemorrhagic shock; circulatory dynamics, recognition and treatment. Surgery, 1944, 16, 430.

20. Eaton, R. M., Pulmonary edema : experimental observations on dogs following acute peripheral blood loss. J. Thoracic Surg., 1947, 16, 668.

21. Olsen, W. H., Guttman, H., Levinson, S. O., and Necheles, H., Circulating time in shock. War Med., 1941, 1, 830.

22. Gibson, J. G., 2nd, and Evans, W. A., Jr., Clinical studies of blood volume. II. The relation of plasma and total blood volume to venous pressure, blood velocity rate, physical measurements, age, and sex in 90 normal humans. J. Clin. Invest., 1937, $16,317$.

23. Cohn, J. E., and Shock, N. W., Blood volume studies in middle aged and elderly males. Am. J. M. Sc., 1949, 217, 388.

24. Reeve, E. B., and Veall, N., A simplified method for the determination of circulating red-cell volume with radioactive phosphorus. J. Physiol., 1949, 108, 12.

25. Barnes, D. W. H., Loutit, J. F., and Reeve, E. B., A comparison of estimates of circulating red blood cell volume given by Ashby marked red cell method and the T-1824 hematocrit method in man. Clin. Sc., 1948, 7, 135.

26. Kelly, F. J., Simonsen, D. H., and Elman, R., Blood volume determination in the human with red cells containing radioactive phosphorus $\left(\mathrm{P}^{22}\right)$ and with pure human albumin. J. Clin. Invest., 1948, 27, 795.

27. Campbell, W. N., Sokalchuk, A., and Penman, R., Validity of T-1824 in plasma volume determinations in human. Am. J. Physiol., 1948, 152, 563.

28. Mather, K., Bowler, R. G., Crooke, A. C., and Morris, C. J. O. R., Precision of plasma volume determinations by Evans blue method. Brit. J. Exper. Path., 1947, 28, 12.

29. Price, P. B., and Longmire, W. P., Use of T-1824 in plasma volume determinations. Bull. Johns Hopkins Hosp., 1942, 71, 51. 